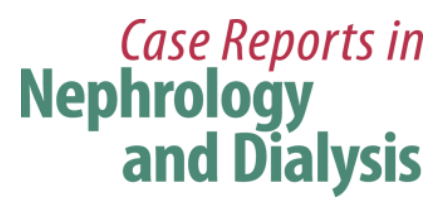

Case Rep Nephrol Dial 2016;6:106-113

DOI: $10.1159 / 000449129$

Published online: September 13, 2016

This article is licensed under the Creative Commons Attribution-NonCommercial 4.0 International License (CC BY-NC) (http://www.karger.com/Services/OpenAccessLicense). Usage and distribution for commercial purposes requires written permission.

\title{
A Case of Transforming Growth Factor- $\beta$-Induced Gene-Related Oculorenal Syndrome: Granular Corneal Dystrophy Type II with a Unique Nephropathy
}

\author{
Yoichi Iwafuchi $^{a}$ Tetsuo Morioka $^{b}$ Yuko Oyama $^{a} \quad K^{2}$ andai Nozu \\ Kazumoto Iijima ${ }^{c}$ Ichiei Narita ${ }^{d}$ \\ ${ }^{a}$ Department of Internal Medicine, Koseiren Sanjo General Hospital, Sanjo, Japan; \\ ${ }^{b}$ Department of Internal Medicine, Kidney Center, Shinrakuen Hospital, Niigata, Japan; \\ 'Department of Pediatrics, Kobe University Graduate School of Medicine, Kobe, Japan; \\ ${ }^{\mathrm{d}}$ Division of Clinical Nephrology and Rheumatology, Niigata University Graduate School \\ of Medical and Dental Sciences, Niigata, Japan
}

\section{Keywords}

Granular corneal dystrophy type II - Transforming growth factor- $\beta$-induced gene · Oculorenal syndrome $\cdot$ Next-generation sequencing $\cdot$ Extracellular matrix Protein-protein interactions

\begin{abstract}
Many types of inherited renal diseases have ocular features that occasionally support a diagnosis. The following study describes an unusual example of a 40-year-old woman with granular corneal dystrophy type II complicated by renal involvement. These two conditions may coincidentally coexist; however, there are some reports that demonstrate an association between renal involvement and granular corneal dystrophy type II. Granular corneal dystrophy type II is caused by a mutation in the transforming growth factor- $\beta$-induced (TGFBI) gene. The patient was referred to us because of the presence of mild proteinuria without hematuria that was subsequently suggested to be granular corneal dystrophy type II. A kidney biopsy revealed various glomerular and tubular basement membrane changes and widening of the subendothelial space of the glomerular basement membrane by electron microscopy. How-
\end{abstract}




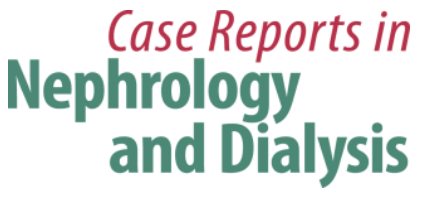

Case Rep Nephrol Dial 2016;6:106-113

DOI: $10.1159 / 000449129$

(C) 2016 The Author(s). Published by S. Karger AG, Basel www.karger.com/cnd

Iwafuchi et al.: A Case of Transforming Growth Factor- $\beta$-Induced Gene-Related Oculorenal Syndrome: Granular Corneal Dystrophy Type II with a Unique Nephropathy

ever, next-generation sequencing revealed that she had no mutation in a gene that is known to be associated with monogenic kidney diseases. Conversely, real-time polymerase chain reaction, using a simple buccal swab, revealed TGFBI heteromutation (R124H). The TGFBI protein plays an important role in cell-collagen signaling interactions, including extracellular matrix proteins which compose the renal basement membrane. This mutation can present not only as corneal dystrophy but also as renal disease. TGFBI-related oculorenal syndrome may have been unrecognized. It is difficult to diagnose this condition without renal electron microscopic studies. To the best of our knowledge, this is the first detailed report of nephropathy associated with a TGFBI mutation.

\section{Introduction}

Many types of inherited renal diseases have ocular features that are helpful in diagnosis [1]. We have observed a case of renal involvement complicated by granular corneal dystrophy type II (GCD2). GCD2, also known as Avellino corneal dystrophy (CD), is an autosomal dominant disorder caused by a mutation in the transforming growth factor- $\beta$-induced (TGFBI) gene [2]. This mutation can be found in several distinct autosomal dominant genetically determined cases of $\mathrm{CD}$; however, it is not known whether this mutation produces other clinical manifestations other than CD. TGFBI proteins (TGFBIp) interact with several extracellular matrix (ECM) components [3, 4]. A mutation in this gene may actually influence basement membrane organization.

We believe that our study was a type of oculorenal syndrome associated with a TGFBI mutation, which remains to be acknowledged.

\section{Case Report}

A 40-year-old woman was evaluated for a 20-year history of proteinuria. She was not taking any medication, and her physical examination was unremarkable. She did not have any deafness or visual disturbances. She presented with a urinary protein level of $1.5 \mathrm{~g} /$ day. Her urinary sediment demonstrated $<1$ erythrocytes and leukocytes per high-power field. Complete blood cell results were normal. The following clinical laboratory values were noted: serum urea nitrogen (BUN), $14.9 \mathrm{mg} / \mathrm{dl}$; creatinine (Cre), $0.79 \mathrm{mg} / \mathrm{dl}$; total cholesterol, $189 \mathrm{mg} / \mathrm{d}$; total protein, $6.4 \mathrm{~g} / \mathrm{dl}$; and albumin, $3.9 \mathrm{~g} / \mathrm{dl}$. The levels of C-reactive protein, immunoglobulins (Ig), and total complement, C3, C4, and C1q were all normal. Tests for antinuclear antibody, hepatitis B virus surface antigen, hepatitis C virus antibody, and cryoglobulins were all negative. All other laboratory tests were within normal limits. Results of a chest X-ray and an electrocardiogram were normal. Renal ultrasound and computed tomography revealed normal kidneys.

A kidney biopsy, performed using light microscopy, revealed 11 glomeruli, 1 of which was obsolete or sclerosed (fig. 1a). Light microscopy did not demonstrate any remarkable changes in the glomeruli (fig. 1b). Focal tubular atrophy with dilation of peritubular capillaries and focal infiltration of small round cells were observed. Immunostaining revealed no significant deposits of IgG, IgA, or C3. Clinical and histopathological findings confirmed the diagnosis of minor glomerular lesions. We observed the patient without the administration of drugs. After 7 years, the patient developed mild hypertension and began taking $4 \mathrm{mg} /$ day of losartan potassium. The patient's mild proteinuria (1-1.5 g/g Cre) continued, and her 


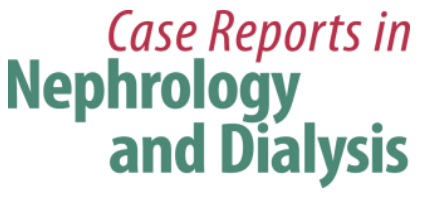

Case Rep Nephrol Dial 2016;6:106-113

DOI: $10.1159 / 000449129$

(C) 2016 The Author(s). Published by S. Karger AG, Basel www.karger.com/cnd

Iwafuchi et al: A Case of Transforming Growth Factor- $\beta$-Induced Gene-Related Oculorenal Syndrome: Granular Corneal Dystrophy Type II with a Unique Nephropathy

renal function was mildly decreased. After 10 years, the patient was re-admitted for additional evaluation of proteinuria. Laboratory testing revealed the following: urinary protein level of $1.5 \mathrm{~g} /$ day, BUN level of $15.0 \mathrm{mg} / \mathrm{dl}$, and Cre level of $0.94 \mathrm{mg} / \mathrm{dl}$. Approximately 2 years before her second admission, the patient complained of mild blurred vision and was diagnosed with CD. Slit-lamp examination revealed a large number of gray-white central granular and linear opacities in both eyes (fig. 2); therefore, we diagnosed her condition as GCD2. A second kidney biopsy was performed under light microscopy, revealing 18 glomeruli, 6 of which were obsolete or sclerosed (fig. 3a). The glomeruli were slightly enlarged with segmental mesangial proliferation (fig. 3b). Segmental double contours of the glomerular capillary walls were also observed (fig. 3c). Focal tubular atrophy with mild interstitial inflammation, dilation of peritubular capillaries, and segmental thickening of tubular basement membranes (TBM) were observed. Several foam cells were noted in the interstitium (fig. 3d). Immunofluorescent examination revealed no significant deposits of immunoglobulins or complement components. Congo red staining was negative for amyloid. Electron microscopic examination of the second biopsy revealed no electron dense deposits. The subendothelial space was widened, and irregularity of the glomerular basement membrane (GBM) was segmentally observed. Segmental irregular thinning, basket-waving, duplication, lamellation, and reticulation of GBM and TBM were observed partially and slightly (fig. 3e-i). Immunostaining of the $\alpha-5$ chains of type IV collagen was normal.

Upon her renal pathological findings, we assumed the existence of a genetic cause. After obtaining informed consent, we collected DNA from the patient. The genome DNA was extracted from the whole blood, and targeted next-generation sequencing of candidate genes for inherited renal diseases was negative (online suppl. table S1; for all online suppl. material, see www.karger.com/doi/10.1159/000449129). Real-time polymerase chain reaction using a simple buccal swab (Avellino Labs Universal Test ${ }^{\circledR}$; ALUT) revealed TGFBI heteromutation (R124H). We speculated that this condition was a novel case of oculorenal syndrome associated with TGFBI mutation. Because of the patient's condition, we analyzed her parents and daughter. Her 74-year-old father had the same mutation of TGFBI (R124H) and was diagnosed with relatively mild GCD2. Her 77-year-old mother and 26-year-old daughter, however, did not have mutated TGFBI (R124H) or GCD2. Her father had no proteinuria but had a slightly elevated level of urinary $\mathrm{N}$-acetyl- $\beta$-D-glucosaminidase (3.0 U/g Cre); however, his renal function was normal (serum Cre, $0.79 \mathrm{mg} / \mathrm{dl}$ ).

Subsequently, the patient was again treated in our outpatient clinic with $4 \mathrm{mg} /$ day of losartan potassium but with no immunosuppressive agents.

\section{Discussion}

We have reported an unusual case of renal involvement and GCD2 with TGFBI heteromutation. These two conditions may coincidentally coexist; however, findings demonstrating an association between renal involvement and GCD2 have been presented.

The TGFBIp (also known as ßig-h3, keratoepithelin) is a 68-kDa ECM protein with four evolutionary conserved fasciclin-1 domains and a carboxy-terminal Arg-Gly-Asp sequence [5]. This protein participates in many physiological processes, including morphogenesis, adhesion/migration, tumorigenesis, angiogenesis, wound healing, and inflammation [6]. TGFBIp is found in ECM of several human tissues and is abundant in the cornea. Mutations of the human TGFBI gene have been linked to several autosomal dominant multiple types of CD, including GCD2. Almost all cases of GCD2 are caused by TGFBI gene mutations (5q31), 
particularly p.Arg124His (R124H) [2]. In a previous study, TGFBI gene mutation was estimated to have a prevalence of at least 11.5 affected people per 10,000 individuals in Korea [7].

According to embryonic expression studies using a mouse knock-out model of TGFBI, Schorderet et al. [8] speculated that functional loss of TGFBI affects several mesodermderived structures. TGFBIp is associated with adhesion/migration and ECM interactions. Mutations in adhesion and ECM molecules, such as integrins and laminin- $\beta 2$, play an important role in the pathogenesis of focal segmental glomerulosclerosis [9]; however, thus far, the relationship between TGFBI mutation and kidney disease has not been established.

In an autopsy patient with TGFBI-related CD, pathologic deposits caused by TGFBIp accumulation were only observed in the cornea and in no other tissue or organ, including the kidney; however, an electromicroscopic examination was not performed in that report [10]. TGFBIp was present in the capsule and TBM of the developing kidney [11] and was predominantly localized in the epithelial cells of the collecting ducts as well as the distal proximal tubules [12]. TGFBIp is secreted into the extracellular space and may bind to fibronectin, laminin, and type I, II, and IV collagens [13] as well as integrins [12,13]. Proteomic analysis revealed that TGFBIp is a component of glomerular ECM $[3,4]$, and it exhibits proteinprotein interactions between the following ECM proteins: $\alpha-2$ macroglobulin; $\alpha-1, \alpha-2$ chain type I collagen; $\alpha-1$ chain type II collagen; $\alpha-1, \alpha-2, \alpha-3$, and $\alpha-4$ chain type IV collagen; fibronectin; and fibrillin-1 [3]. Proteoglycans directly bind to TGFBIp and affect collagen VI aggregation and possibly the interaction between integrin and collagen VI [14]. Binding allows TGFBIp, including ECM proteins, to play an important role in cell-collagen signaling interactions that comprise BM, bone formation, and development as well as cell migration and growth.

In our patient, various pathological findings of GBM and TBM and widening of the subendothelial space of GBM were observed by electron microscopy. A negative genetic analysis of well-known monogenic kidney diseases prompted us to consider that TGFBI mutation could affect the BM of the developing kidneys and produce such BM findings. The findings of TBM were more obvious than those of GBM. The pathophysiological mechanisms and the incidence of this condition or genotype-phenotype correlation for TGFBI mutations are not obvious.

Visual disturbances preceded by proteinuria occurred in our patient during her clinical evaluation. If detailed examination of the corneas is not performed, GCD2 may not be observed until middle-age and older. It should be noted that detailed ocular examinations, including cornea assessments, are valuable when diagnosing nephropathy associated with TGFBI mutations. Presently, ALUT testing is beneficial for laser-assisted in situ keratomileusis to protect patients from accelerated vision loss. As demonstrated with our patient, this test is easy and safe to perform when diagnosing patients with nephropathy associated with TGFBI mutations.

In conclusion, we have reported the first case of a unique nephropathy complicated by TGFBI-related CD. We consider that our case was probably a novel type of oculorenal syndrome. TGFBI-related nephropathy remains unknown and is difficult to diagnose without electron microscopic examination. Further reports should be accumulated to determine whether the incidence of renal diseases associated with this mutation may presently be more frequent. Patients with TGFBI-related CDs, including GCD2, should be examined for renal abnormalities. 


\section{Acknowledgement}

The authors are grateful to Dr. S. Hasegawa and Dr. A. Tanabe (Department of Ophthalmology, Koseiren Sanjo General Hospital) for their ophthalmologic examinations, to Avellino Lab USA for interpreting the TGFBI mutational analysis, and to Mr. N. Sakamoto, Ms. S. Tsuchida, Ms. M. Yoshinuma, and Ms. M. Igashima (Department of Pathology, Shinrakuen Hospital) for their technical assistance. This study was partially supported by a grant 'Initiative on Rare and Undiagnosed Diseases' (to I.N.) from Japan Agency for Medical Research and Development.

\section{Statement of Ethics}

The authors have no ethical conflicts to disclose, and the patient provided informed consent.

\section{Disclosure Statement}

The authors declare that they have no relevant financial interests.

\section{References}

1 Izzedine H, Bodaghi B, Launay-Vacher V, Deray G: Eye and kidney: from clinical findings to genetic explanations. J Am Soc Nephrol 2003;14:516-529.

2 Klintworth GK: Corneal dystrophies. Orphanet J Rare Dis 2009;4:7.

-3 Randles MJ, Woolf AS, Huang JL, Byron A, Humphries JD, Price KL, Kolatsi-Joannou M, Collinson S, Denny T, Knight D, Mironov A, Starborg T, Korstanje R, Humphries MJ, Long DA, Lennon R: Genetic background is a key determinant of glomerular extracellular matrix composition and organization. J Am Soc Nephrol 2015;26:3021-3034.

-4 Lennon R, Byron A, Humphries JD, Randles MJ, Carisey A, Murphy S, Knight D, Brenchley PE, Zent R, Humphries MJ: Global analysis reveals the complexity of the human glomerular extracellular matrix. J Am Soc Nephrol 2014;25:939-951.

5 Kawamoto T, Noshiro M, Shen M, Nakamasu K, Hashimoto K, Kawashima-Ohya Y, Gotoh O, Kato Y: Structural and phylogenetic analyses of RGD-CAP/Big-h3, a fasciclin-like adhesion protein expressed in chick chondrocytes. Biochim Biophys Acta 1998;1395:288-292.

6 Thapa N, Lee BH, Kim IS: TGFBIp/Big-h3 protein: a versatile matrix molecule induced by TGF- $\beta$. Int J Biochem Cell Biol 2007;39:2183-2194.

-7 Lee JH, Cristol SM, Kim WC, Chung ES, Tchah H, Kim MS, Nam CM, Cho HS, Kim EK: Prevalence of granular corneal dystrophy type 2 (Avellino corneal dystrophy) in the Korean population. Ophthalmic Epidemiol 2010;17:160-165.

-8 Schorderet DF, Menasche M, Morand S, Bonnel S, Büchillier V, Marchant D, Auderset K, Bonny C, Abitbol M, Munier FL: Genomic characterization and embryonic expression of the mouse Bigh3 (Tgfbi) gene. Biochem Biophys Res Commun 2000;274:267-274.

-9 Chen YM, Liapis H: Focal segmental glomerulosclerosis: molecular genetics and targeted therapies. BMC Nephrol 2015;16:101.

10 El Kochairi I, Letovanec I, Uffer S, Munier FL, Chaubert P, Schorderet DF: Systemic investigation of keratoepithelin deposits in TGFBI/BIGH3-related corneal dystrophy. Mol Vis 2006;12:461-466.

11 Billings PC, Whitbeck JC, Adams CS, Abrams WR, Cohen AJ, Engelsberg BN, Howard PS, Rosenbloom J: The transforming growth factor- $\beta$-inducible matrix protein $\beta$ ig-h3 interacts with fibronectin. J Biol Chem 2002;277:28003-28009.

12 Kim JE, Jeong HW, Nam JO, Lee BH, Choi JY, Park RW, Park JY, Kim IS: Identification of motifs in the fasciclin domains of the transforming growth factor- $\beta$-induced matrix protein $\beta$ ig-h3 that interact with the $\alpha v \beta 5$ integrin. J Biol Chem 2002;277:46159-46165. 


\section{Case Reports in Nephrology and Dialysis}

\section{DOI: $10.1159 / 000449129$ \\ (C) 2016 The Author(s). Published by S. Karger AG, Basel} www.karger.com/cnd

Iwafuchi et al.: A Case of Transforming Growth Factor- $\beta$-Induced Gene-Related Oculorenal Syndrome: Granular Corneal Dystrophy Type II with a Unique Nephropathy

13 Kim MO, Yun SJ, Kim IS, Sohn S, Lee EH: Transforming growth factor- $\beta$-inducible gene-h3 ( $\beta$ ig-h3) promotes cell adhesion of human astrocytoma cells in vitro: implication of $\alpha 6 \beta 4$ integrin. Neurosci Lett 2003;336:93-96.

14 Reinboth B, Thomas J, Hanssen E, Gibson MA: Big-h3 interacts directly with biglycan and decorin, promotes collagen VI aggregation, and participates in ternary complexing with these macromolecules. J Biol Chem 2006;281:7816-7824.
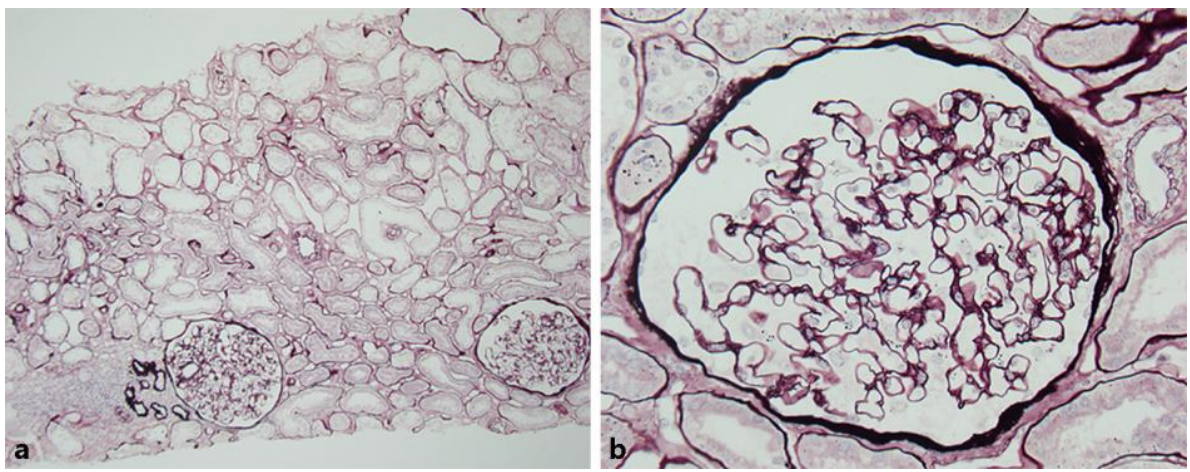

Fig. 1. a Normal appearance of the glomeruli. Focal tubular atrophy with dilation of the peritubular capillaries and focal infiltration of small round cells (periodic acid-silver methenamine stain, original magnification $\times 48$ ). b Glomeruli revealing unremarkable changes by light microscopic examination (periodic acidsilver methenamine stain, original magnification $\times 400$ ).
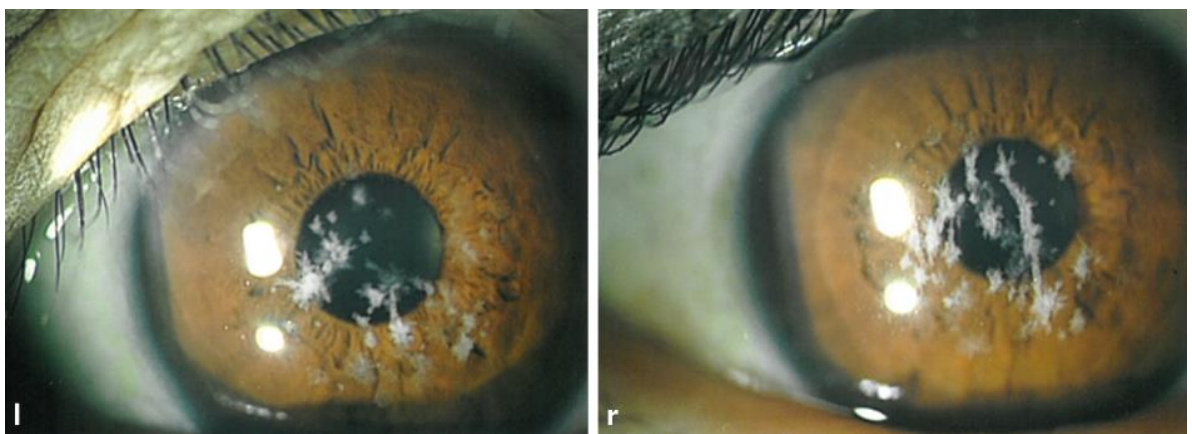

Fig. 2. Bilateral slit-lamp examination demonstrating areas of fused crumb-like white stromal opacities resulting in elongated and stellate shapes. $\mathrm{l}=$ Left; $\mathrm{r}=$ right. 


\begin{tabular}{|c|c|c|}
\hline \multirow{2}{*}{$\begin{array}{l}\text { Case Reports in } \\
\text { Nephrology } \\
\text { and Dialysis }\end{array}$} & \multicolumn{2}{|c|}{ Case Rep Nephrol Dial 2016;6:106-113 } \\
\hline & DOI: $10.1159 / 000449129$ & $\begin{array}{l}\text { O } 2016 \text { The Author(s). Published by S. Karger AG, Basel } \\
\text { www.karger.com/cnd }\end{array}$ \\
\hline
\end{tabular}

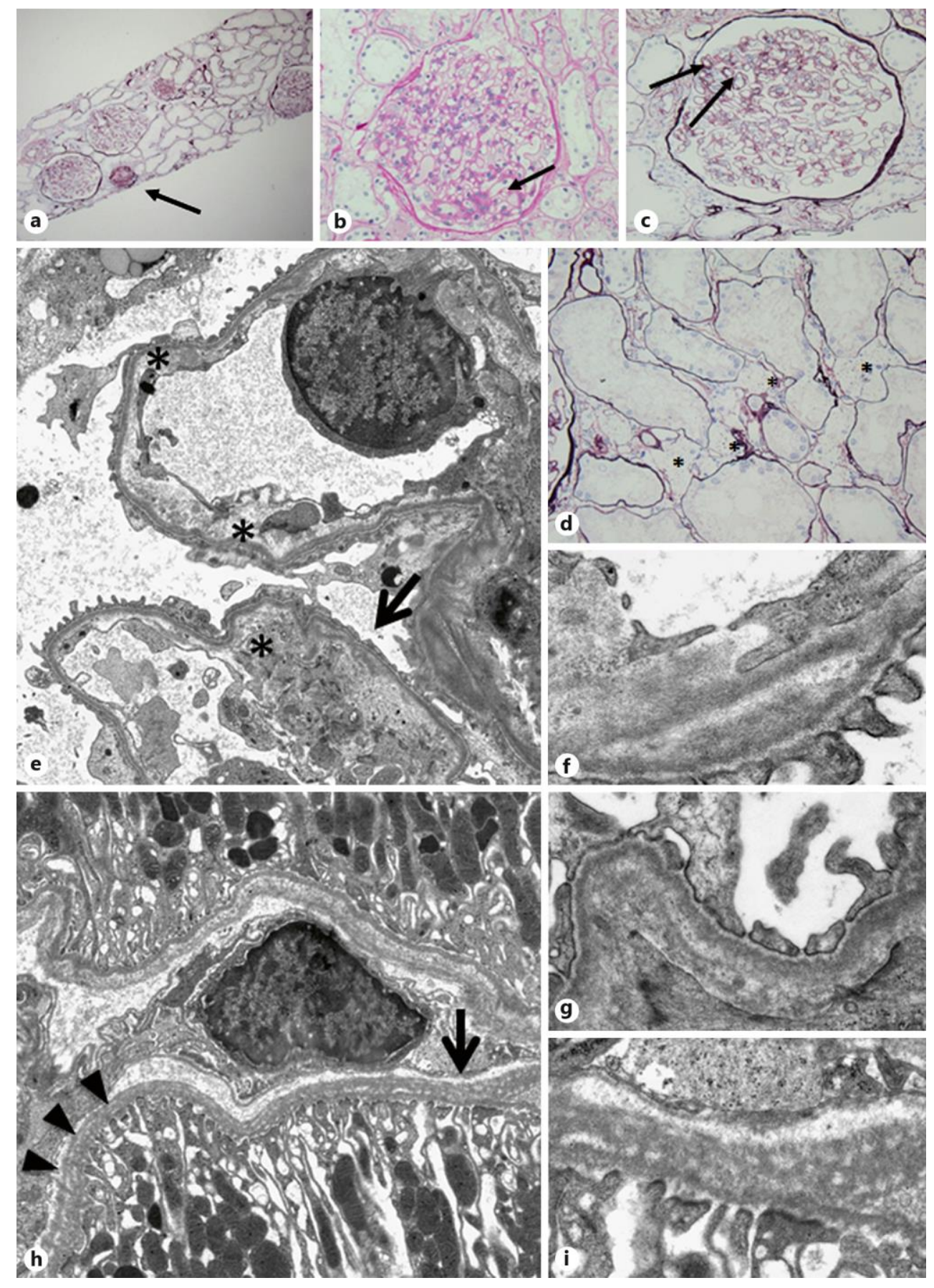




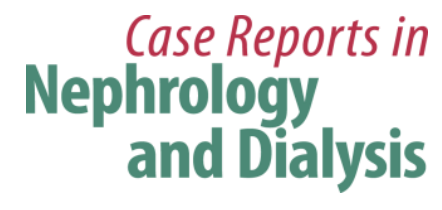

Case Rep Nephrol Dial 2016;6:106-113

Fig. 3. a Light microscopic examination revealing 18 glomeruli. Six (arrow) were obsolete or sclerosed. The glomeruli were slightly enlarged with segmental mesangial proliferation. Focal tubular atrophy with mild interstitial inflammation was noted (periodic acid-silver methenamine stain, original magnification $\times 48$ ). b The glomerulus displaying a mild segmental increase in the mesangial matrix (arrow) (periodic acidSchiff stain, original magnification $\times 400$ ). c Slightly enlarged glomerulus with segmental mesangial proliferation. Segmental double contours of the glomerular capillary walls (arrows) were observed (periodic acid-silver methenamine stain, original magnification $\times 400$ ). $d$ Several foam cells (asterisks) were noted in the interstitium. Focal tubular atrophy with dilation of peritubular capillaries was also noted (periodic acid-silver methenamine stain, original magnification $\times 400$ ). e Separation of the endothelial cell from the underlying GBM (asterisks). Slightly irregular appearance, such as partial thinning and duplication of the GBM with partial effacement of foot processes (arrow) (electron microscopy, original magnification $\times 2,000$ ). $f$ Higher magnification displaying partial duplication of the GBM (electron microscopy, original magnification $\times 12,000)$. $\mathbf{g}$ Higher magnification displaying partial irregularity of the GBM (electron microscopy, original magnification $\times 10,000)$. $\mathbf{h}$ Diffuse irregular distribution with reticulation (arrows) and lamellation (arrowheads) of the TBM (electron microscopy, original magnification $\times 2,000$ ). i Higher magnification displaying reticulation of the TBM (electron microscopy, original magnification $\times 10,000$ ). 